\title{
Adoption of the low carbon society policy in locally-governed urban areas: experience from Thai municipalities
}

\author{
Surawut Chomaitong • Ranjith Perera
}

Received: 21 January 2013 / Accepted: 25 April 2013 / Published online: 21 May 2013

C The Author(s) 2013. This article is published with open access at Springerlink.com

\begin{abstract}
Low Carbon Society (LCS) has emerged as a holistic approach to reduce carbon (C) emissions that result from human activities. Although there has been successful implementation of the LCS approach in some cities of developed countries, it is more difficult in developing countries like Thailand. The objectives of this paper are to present drivers and barriers affecting the abilities of three regional cities of Thailand to combine LCS activities with their strategies. Lessons learned from this study will allow for sharing these experiences with municipalities in other developing countries. This research was based on interviews of key informants representing state agencies and local public service associations. It was found that no particular driver significantly influenced local government agencies to implement LCS activities. Conversely, there were financial and managerial barriers to implementing (C) reduction activities. This paper identifies the need for more specific and tailor-made assistance to allow urban municipalities to shift towards LCS activities by considering their individual strengths and weaknesses. Moreover, stakeholders' understanding of the advantages of implementing LCS activities within locally governed areas was found to be critical for success. The paper concludes that climate change mitigation activities not only reduce greenhouse gas (GHG) emissions but also produce tangible benefits such as improvement the quality of life of people. Such an approach can motivate stakeholders to pursue LCS as a shared goal.
\end{abstract}

S. Chomaitong $(\bowtie) \cdot$ R. Perera

Urban Environment Field of Study, School of Environment, Resources and Development, Asian Institute of Technology, P.O. Box 4, Klong Luang, Pathumthani 12120 Bangkok, Thailand e-mail: s25chomaitong@hotmail.com

S. Chomaitong

e-mail: st107338@ait.ac.th

R. Perera

e-mail: ranjith@squ.edu.com

R. Perera

Department of Civil and Architectural Engineering, College of Engineering, Sultan Qaboos University, PO Box 33, 123 AL Khoudh, Oman

e-mail: ranjithp@ait.ac.th 
Keywords Climate change mitigation - Low Carbon Society · Barrier · Driver - Local government $\cdot$ Thailand

$\begin{array}{ll}\text { Abbreviations } \\ \text { APEC } & \text { Asia-Pacific Economic Cooperation } \\ \text { ADEME } & \text { French Environment and Energy Management Agency } \\ \text { BMA } & \text { Bangkok Metropolitan Administration } \\ \text { CO } & \text { Carbon dioxide } \\ \text { CDM } & \text { Clean Development Mechanism } \\ \text { CMM } & \text { Chiang Mai Municipality } \\ \text { EPPO } & \text { Energy Policy and Planning Office } \\ \text { GHG } & \text { Greenhouse gas } \\ \text { IGES } & \text { Institute for Global Environmental Strategies } \\ \text { IPCC } & \text { Intergovernmental Panel on Climate Change } \\ \text { KKM } & \text { Khon Kaen Municipality } \\ \text { LCS } & \text { Low Carbon Society } \\ \text { LSD } & \text { Least Significant Difference } \\ \text { LCC } & \text { Low Carbon Cities } \\ \text { MOEJ } & \text { Ministry of the Environment Japan } \\ \text { MoE } & \text { Ministry of Energy } \\ \text { MoI } & \text { Ministry of Interior } \\ \text { NESDB } & \text { National Economic and Social Development Board } \\ \text { NGO } & \text { Non-Government Organization } \\ \text { NSCCM } & \text { National Strategy on Climate Change Management } \\ \text { NMT } & \text { The National Municipal League of Thailand } \\ \text { ONEP } & \text { Office of Natural Resources and Environmental Policy and planning } \\ \text { PAO } & \text { Provincial Administration Organization } \\ \text { PPP } & \text { Public Private Partnership } \\ \text { RTG } & \text { The Royal Thai Government } \\ \text { RYM } & \text { Rayong Municipality } \\ \text { TAT } & \text { Tourism Authority of Thailand } \\ \text { TRF } & \text { Thailand Research Fund } \\ \text { TGO } & \text { Thailand Greenhouse Gas Management Organization } \\ \text { UN } & \text { United Nation } \\ \text { UNFCCC } & \text { United Nations Framework Convention on Climate Change } \\ \text { WAI } & \text { Weighted Average Index } \\ & \end{array}$

\section{Introduction}

Greenhouse gases (GHG) emitted by human activities are considered one of the major causes of climatic change (Smith 2006). Among GHG mitigation approaches, the Low Carbon Society (LCS) approach is a holistic idea that calls for behavioral changes among people. Its goal is to reduce GHG emissions to levels that can be naturally absorbed (MOEJ 2007). The LCS approach is particularly relevant for urban areas which have GHG emitting sectors in great numbers. Therefore, local government bodies managing urban areas have a leadership role to play in transforming urban societies to low carbon societies (APEC 2010). There are several arguments to support the notion that local governments should be the point 
at which strategies are implemented to promote LCS concepts in developing countries like Thailand.

Developing countries are projected to be responsible for approximately $61 \%$ of global GHG emissions by the year 2030 (Koh et al. 2011). Recent studies focused on the potential of major sectors such as transportation and energy. However, we also need to clearly understand the challenges faced by local government in implementing climate mitigation strategies, especially in developing countries (Dhakal 2010). Activities in cities are the major sources of GHG emissions. Mitigations strategies are best implemented through local governments. They have an official administrative duty to manage their city and work closely with local people. They have authority to convince local people to comply with LCS approaches and can efficiently solve problems that arise due to local circumstances (Grimmond et al. 2010; Larsen and Gunnarsson-Ostling 2009; Paung-ngum 2005; Orlansky 2000).

Thailand is a rapidly developing country that will emit more GHGs in future if the present rate of urbanization and industrialization continues unabated. Thailand is ranked among the top 25 GHG emitting countries (NESDB 2009). The Royal Thai Government (RTG) has implemented several policies and pilot projects through its ministries and line agencies in order to reduce GHG emissions. In 2002, Thailand ratified the United Nations Framework Convention on Climate Change Kyoto Protocol as a 'Non-Annex 1' country. As such, it has the responsibility to reduce GHG emissions by $15-40 \%$ by year 2020 (TRF 2010). Several other measures were taken by the RTG. In 2008, the RTG created the National Policy on Climate Change Management as well as a National Strategy on Climate Change Management (NSCCM) which recognizes GHG emission reduction as one of its main strategies (NESDB 2009). The Thailand Greenhouse Gas Management Organization (TGO) was established in 2007 to promote and implement Clean Development Mechanism (CDM) projects and a (C) credit market in the country (TGO 2007).

The RTG endeavors to stimulate local government actions to implement mitigation activities. The Office of Natural Resources and Environmental Policy and Planning (ONEP) in collaboration with Ministry of Energy (MoE) launched a pilot project under the NSCCM to enable some local governments to utilize their solid waste collections as alternate energy sources (NMT 2008; ONEP 2009). Also the TGO initiated a pilot project to assess (C) footprints of local governments. In accordance with the Decentralization Act of 1999, the RTG transferred some authority to local governments. This authorizes local agencies to engage in projects such as environment and natural resource conservation as well as basic infrastructure development. In turn, may promote LCS objectives may be promoted. However, there has been no directive to compel local governments to respond directly with climate change mitigation. The RTG has taken several initiatives to promote LCS with local strategies, but these have been implemented by few of the local government bodies. This is because anti-poverty, food security, and urban infrastructure programs have higher priority than mitigation of climate change (Laukkonen et al. 2009). This is a major factor affecting implementation of LCS concepts in developing countries. Yuan et al. (2010) showed that LCS approaches have been developed by relevant agencies of developed countries including Japan, United Kingdom, and Finland. These countries have rather complete capabilities to promote this concept so that practical actions result. In the case of developing countries, integrating the LCS concept with local government strategies is not an easy task. Moreover, there are several complicating factors. This paper will present the major drivers and barriers affecting integration of LCS with municipal strategies. The most serious barriers and most important drivers will be presented. Recommendations will be made in the lessons learned section below. 


\section{Factors that affect the achievement of LCS goal at the local government level}

The Low Carbon Society concept is a holistic approach that can help to efficiently control GHG emissions. Its measures are designed to encourage stakeholders to emit less GHG and do so at levels low enough to be absorbed by nature. In principle, there are four major strategies to accomplish the goal of developing a LCS. They are (i) changing peoples' lifestyles, (ii) using renewable energy and energy efficient devices, (iii) expanding green areas, and (iv) promoting LCS policies in conjunction with developmental policies. These activates should be applied at both local and national levels (APEC 2010; MOEJ 2007; Skea and Nishioka 2008). However, it is necessary to seriously consider the factors influencing capabilities of local governments before beginning an LCS approach.

\subsection{Drivers}

Firstly, willingness of leadership is an extremely important driver of policy decision making in both public and private organizations (VijayaVenkataRaman et al. 2011; Stephens et al. 2008). Burch (2010) highlighted that a leader always transfers his or her interests into concrete actions. Conversely, lack of interest is a serious barrier (Lorenzoni et al. 2007). In this way, if a mayor has a strong determination for GHG reduction, he or she will impose measures as instruments to stimulate local officials to comply with the LCS approach (Hillmer-Pegrama et al. 2012). Also, a central government has authority to manage the actions of all stakeholders in reducing GHG (Tompkins and Adger 2005). It can also warrant that long term actions will be sustained (Byrne et al. 2007). National incentive policies can be a tool to encourage public organizations at all levels to engage in mitigation approaches (Hardoy and Lankao 2011; Oliveira 2009). In this paper, we examine to two incentive policies for local governments. The policies are financial incentives and technology transfer policies.

Local governments are responsible for many functions while they have limited budgets (Roy 2009). Consequently, central government subsidies are essential in order for local governments to purchase high cost items such as modern machinery (Byrne et al. 2007). Central governments can use international financial support at local government levels (Rübbelke 2011). They also can provide financial incentives for private sector purchase of modern machinery (Zhang and Maruyama 2001). Through technology transfer, central governments can link technology of developed countries to their stakeholders at all level of government (Lybbert and Sumner 2012; Rübbelke 2011). This is one way that capabilities of organizations can be developed to mitigate GHG (Tompkins and Adger 2005).

Lastly, coordination among stakeholders is a crucial element for formulating mitigation policies (Liu and Deng 2011). This approach considers of all dimensions from international to local level stakeholders and includes all sectors in society (VijayaVenkataRaman et al. 2011; Laukkonen et al. 2009). Hardoy and Lankao (2011) suggested that public service organizations could participate in formulating climatic change mitigation policies with local government. Universities can also help municipalities to adopt climatic change mitigation policies (Hillmer-Pegrama et al. 2012).

\subsection{Barriers}

Although there are some drivers that influence the adoption of LCS approaches by municipal organizations, barriers to their adoption need to be considered. In this paper, barriers to adoption of LCS programs can be grouped into four types based upon the perspectives of 
Roy (2009), IPCC (2007) and Winkler et al. (2007). The four barriers are financial, technological, social, and managerial.

Financial barriers are linked to technological issues. Machinery used in the LCS approach is expensive (Becken 2005; Vadas et al. 2007). Insufficient financial resources to cover high investment costs coupled with lack of incentive policies can constrain both public and private organizations in developing countries (IPCC 2007; Betsill 2001; Vadas et al. 2007; Kheshgi et al. 2012).

Applying low (C) technology is a major component of the LCS approach. However, low (C) and energy efficient technologies are not available in developing countries. This is because they have insufficient knowledge to invent such low (C) technologies. Thus, they have to import those technologies from developed countries. Such technology is extremely expensive. This discourages organizations and government agencies in developing countries from acquiring equipment for low (C) technology projects (Roy 2009; IGES 2008). Furthermore, it is difficult for local government agencies to utilize complicated programs that require technical skills (Bader and Bleischwitz 2009).

Social barriers are primarily the attitudes of people about the importance of climatic change mitigation (Winkler et al. 2007; Jaber 2002). Efficient mitigation policy cannot be formulated if politicians place little importance on climate change mitigation. Moreover, strong cooperation among local governmental agencies is crucial for implementing local mitigation activities. Typically, local officials do not respond well because of their working styles. Local officials prefer to perform routine duties (Burch 2010; Wang et al. 2007; Fleming and Webber 2004).

The last limitation of local government is the managerial barrier. It arises from poor organizational management. Local government agencies are not equipped to redevelop administrative systems such as human resources management. This directly impacts their abilities to develop local climate policies and activities (Wiruchnipawan 2003; Betsill 2001). Local policy makers lack information about mitigation approaches and implementation of these activities within urban communities (Fleming and Webber 2004; Oberheitmann 2012). Local officials perceive their work load as great. So, local planners consider this mission a minor priority (Oliveira 2009). However, governmental policies on climatic change can cause local governmental agencies to treat GHG emission as a serious problem (Jaber 2002; Winkler et al. 2007). Thus, without national policies addressing mitigation efforts, stakeholders can become discouraged from participating in this global effort (Garbuzova and Madlener 2012).

\section{Data and methodology}

The authors conducted this study in selected municipalities at the second tier of local government hierarchy in Thailand. These are called Nakhon Municipalities. It was presumed that the second tier municipalities face barriers to implementation of action plans for climate change management in general and LCS in particular. However, it was discovered that some municipalities have implemented a few projects to achieve the goal of LCS based. They are scattered all over the country. Among them are the Rayong Municipality (RYM) in the Eastern region, Khon Kaen Municipality (KKM) in the Northeastern region, and Chiang Mai Municipality (CMM) in the Northern region (Fig. 1). They are well known in Thailand for good environmental management practices and GHG mitigation actions. Accordingly, RYM, KKM and CMM were selected for the empirical part of the research to examine the drivers and barriers that affect the adoption of LCS by the second-tier local government 


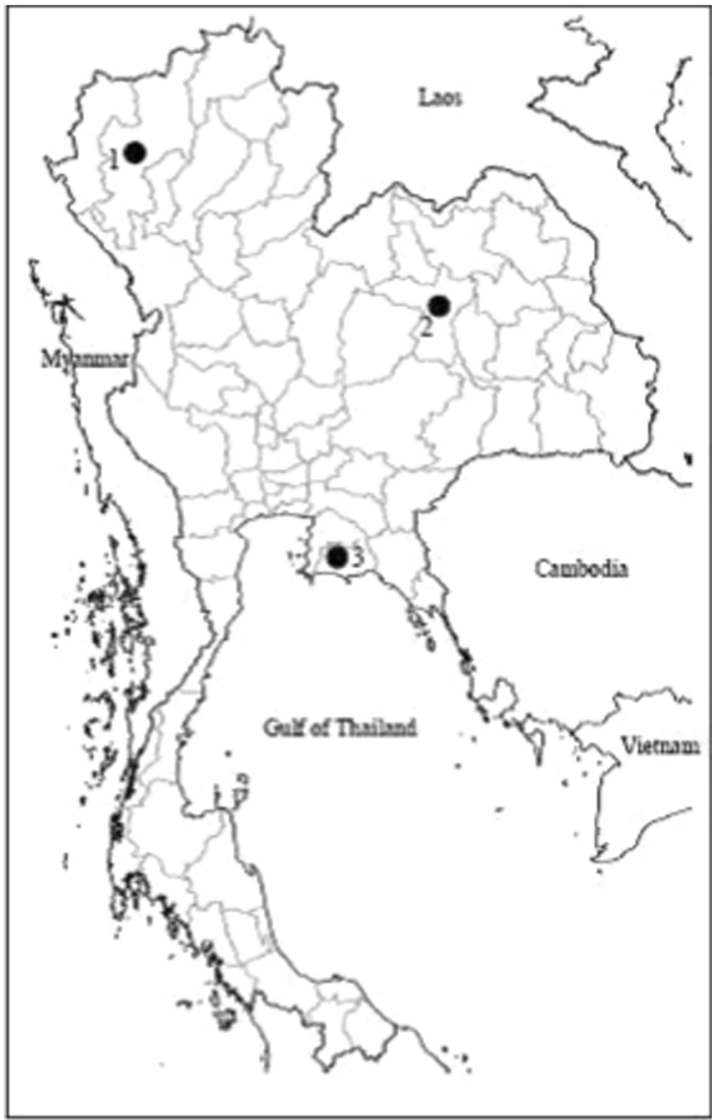

1. Chiang Mai municipality

2. Khon Kaen municipality

3. Rayong municipality

Fig. 1 Location of three municipalities studied in Thailand

bodies in Thailand. It could be argued that the researchers should have selected municipalities that struggle to implement any action at all. This was done because a goal of the current study was to derive benefit from the past experiences of municipalities that already implemented (C) mitigation projects. Their achievements could be used to guide and inspire other local government bodies in the lower tiers.

\subsection{Data collection}

Data was collected from the three municipalities discussed above (RYM, KKM, and CMM) over a 3 month period. Municipalities were selected that implemented (C) mitigation programs in collaboration with other government agencies and public service organizations. Key informants are persons working within the local government agencies, relevant government organizations and public service organizations selected for data collection. This was done in each of the selected municipalities. The first two categories of key informants represent the state and they were drawn from the respective municipalities and the collaborating government agencies such as Provincial Environment Offices, and Provincial Energy Offices. They are elected representatives, civil service administrators, and directors of municipal schools, and senior bureaucrats and technocrats. The rest of the key informants 
represent community activists and consisted of community leaders, representatives of non-governmental organizations (NGOs), local business leaders, and academics.

The selection of key informants was limited to those directly engaged in (C) emission reduction activities in their respective municipalities. A total of 110 key informants were selected from the three municipalities. Of these, there were 36 from RYM, 36 from KKM and 38 from CMM. The three groups of key informants were treated as a single sample containing three subsets. It is emphasized that the focus of the current research is on the similarities and dissimilarities of the drivers and barriers affecting the three municipalities. The research did not attempt to investigate the similarities or dissimilarities of the perceptions between the respondents representing state agencies and community activists. All key informants responded to the same set of questions. The questionnaire focused on the respective municipalities and their activities towards achieving LCS goals. Secondary data was collected from the development and strategic plans of the three municipalities. Focus groups with local community leaders, NGO representatives, academics, and participants from government agencies were done using structured questions. Municipalities meetings related to LCS activities were attended to collect further data.

\subsection{The questions and variables}

There are four types of barriers that affect implementation of LCS activities (Roy 2009, IPCC 2007 and Winkler et al. 2007) These are economic, technological, institutional, nontechnological in nature. The variables in each group of barriers were derived from a literature review and from a pre-study survey. All questions asked the respondents about the extent to which individual barriers influence integration of LCS activities with municipal strategies. Responses were on a scale of $1-5$ corresponding to the following: $5=$ Very much, $4=$ Much, 3 = Neutral, 2 = Low, 1 = Very low.

Moreover, we created a group of questions for structured interviews from the major objectives of the study. The interview questions were created to focus on the opinions of key informants from all groups. Persons interviewed held positions such as Vice-Mayor, Division Head, Provincial Directors of various governmental agencies, NGOs, and community leaders. Interviews lasted for approximately 40-60 min. The questions examined the capabilities of local government agencies, existing environmental conditions, and prospective approaches. The questions were as follows:

- What are the major environmental problems in your city?

- What are the activities are you implementing to mitigate climatic change?

- What is the most serious barrier to implementing activities to mitigate climatic change?

- What are the key drivers contributing the implementing LCS activities by your local government?

- To what extent do you understand the multiple benefits of climatic change mitigation and sustainable development policy?

- What are the ways to increase stakeholder participation in LCS activities?

- What are the suitable approaches to help your municipality engage in future LCS activities?

\subsection{Data analysis}

This study used both qualitative and quantitative methods to develop a complete understanding of the specific issues in terms of limitations and drivers influencing municipal organizations adopting LCS approaches. Secondary data such as municipal reports and plans were used to do qualitative analysis. A scale was used to transform the respondents' 
qualitative perceptions for statistical analysis. Weighted Average Index (WAI) was used to analyze respondents' opinions. WAI was used transform the opinions of respondents from a nominal scale (very high-very low) into numeric scores. The scores were classified into five levels: $0-0.20=$ very low influence; $0.21-0.40=$ low influence; $0.41-0.60=$ moderate influence; $0.61-0.80=$ high influence; $0.81-1=$ very high influence. One-way ANOVA and Least Significance Difference (LSD) were used to make a comparison between the mean values of WAI among three test groups.

Moreover, interpretation of the results of the multiple comparison technique, shown in Tables 3 and 4, is that WAI values in the same row superscripted with ' $a$ ' are significantly different from those subscripted with ' $b$ ' $(p$ value $<0.05)$ according to pair-wise comparison using one-way ANOVA test and LSD's test. In Tables 3 and 4, parameter values with superscripted with ' $a$ ' are significantly different than those subscripted with 'b'. Values with the same superscript, 'a' or 'b', are not significantly different. Parameter values superscripted with 'ab' are not significantly different from values superscripted with either ' $a$ ' or ' $b$ '. Higher WAI values indicate a stronger response to the question.

\section{Study areas profiles and related (C) mitigation actions}

This study was conducted at three municipalities in separate regions of Thailand. All of these municipalities are larger cities and likely to emit significant amounts of GHGs. Rayong municipality (RYM) is a city at the eastern region of Thailand. It had 58,739 residents in 2009 and covers $16.95 \mathrm{~km}^{2}$. Approximately $10 \%$ of its area (170 ha) is dedicated to public green spaces, which translates to $28.75 \mathrm{~m}^{2}$ per person. The total population is approximately 62,000 persons including those not registered as residents of the municipality. It is situated on the shore of the Gulf of Thailand. RYM is close to Mab Ta Put Industrial Estate, known as a source of air pollution and waste water. RYM is affected by transboundary pollutants emitted by Mab Ta Put Industrial Estate. Waste water discharge into the Rayong River by fish processing plants is another serious environmental problem (RYM 2010).

Khon Kaen municipality is located in the Northeastern region. Its population was 116,157 in 2009 in an area of $46 \mathrm{~km}^{2}$. However, when the non-registered population is included, KKM has approximately 450,000 residents. The city is important as a center of regional commerce, service, and education. It has 190 ha of green space or $18.61 \mathrm{~m}^{2}$ per person. The main environmental problem in KKM is solid waste because of its large population (KKM 2010).

Chieng Mai Municipality (CMM) is the biggest city in the Northern region of Thailand. It had 146,346 residents in 2008 within its $40.21 \mathrm{~km}^{2}$. When the nonregistered population is considered, the total population is approximately 1 million people. CMM has approximately 130 ha or $8.7 \mathrm{~m}^{2}$ per person of green space. CMM is a regional center of commercial and service sectors in the north of Thailand as well as a tourist destination. Its environment problem arises

Table $1 \mathrm{CO}_{2}$ equivalent tons emitted by the waste sector and electrical consumption in three Thai cities

\begin{tabular}{llll}
\hline & Number of population & Waste sector (Ton $\mathrm{CO}_{2}$ eq.) & Electricity consumption (Ton $\mathrm{CO}_{2}$ eq.) \\
\hline - RYM & 58,739 & 25,389 & 54,757 \\
- KKM & 116,157 & 84,315 & 251,074 \\
- CMM & 146,346 & 122,640 & 590,733 \\
\hline
\end{tabular}

Calculations based on the data of local development plans, NESDB 2010, TAT 2010 
Table 2 Major strategies and projects related to LCS activities of three selected Thai municipalities

\begin{tabular}{|c|c|c|}
\hline Municipality & Major strategies & Major projects \\
\hline \multirow[t]{7}{*}{ RYM } & $\begin{array}{l}\text { - Increasing capabilities of waste collection } \\
\text { and disposal system }\end{array}$ & $\begin{array}{l}\text { - Waste collection by private companies } \\
\text { - Developing capability of fertilizer and polymer } \\
\text { energy plants }\end{array}$ \\
\hline & - Economic value-added of solid waste & - Polymer energy plant \\
\hline & $\begin{array}{l}\text { - Reducing solid waste and creating } \\
\text { awareness of people }\end{array}$ & - Increasing participation in waste separation \\
\hline & $\begin{array}{l}\text { - Creating networks and distribution of } \\
\text { environmental information }\end{array}$ & $\begin{array}{l}\text { - Raising awareness and monitoring of } \\
\text { environmental conditions }\end{array}$ \\
\hline & $\begin{array}{l}\text { - Developing energy policies to promote } \\
\text { energy conservation and use of } \\
\text { alternative energy }\end{array}$ & - Creating energy conservation networks \\
\hline & - Conserving bio-diversity & - Restoring the fertility of mangrove areas \\
\hline & $\begin{array}{l}\text { - Educating and creating awareness to } \\
\text { conserve natural resources and the } \\
\text { environment }\end{array}$ & $\begin{array}{l}\text { - Raising constituent participation } \\
\text { - Renovating municipal environmental centers } \\
\text { - Planting trees to mitigate climatic change }\end{array}$ \\
\hline \multirow[t]{5}{*}{ KMM } & $\begin{array}{l}\text { - Natural resources and environmental } \\
\text { management }\end{array}$ & $\begin{array}{l}\text { - Training youth groups, food waste tanks or bins. } \\
\text { Households use these devices to store food } \\
\text { wastes; the municipality collects and utilizes } \\
\text { food waste as a raw material for gasification } \\
\text { - Reducing household waste }\end{array}$ \\
\hline & & - Implementing a citywide Big Cleaning Day \\
\hline & & - Livable community competitions \\
\hline & & $\begin{array}{l}\text { - School level alternative energy conversion of } \\
\text { waste to methane }\end{array}$ \\
\hline & & - Tree planting \\
\hline \multirow[t]{7}{*}{ CMM } & - Raising awareness & - Campaign for conserving the city's climate \\
\hline & & - Protecting old trees \\
\hline & $\begin{array}{l}\text { - Increasing municipal capabilities to } \\
\text { eliminate solid waste }\end{array}$ & $\begin{array}{l}\text { - Green map of the city } \\
\text { - Promoting constituent participation to keep the } \\
\text { city clean }\end{array}$ \\
\hline & - Preventing floods and improving water & - Improving drainage systems \\
\hline & quality & $\begin{array}{l}\text { - Increasing capacity of the city's water treatment } \\
\text { plant }\end{array}$ \\
\hline & - Controlling air and noise pollution & - Monitoring air quality and noise levels \\
\hline & & $\begin{array}{l}\text { - Increasing capabilities of the city to control air } \\
\text { quality }\end{array}$ \\
\hline
\end{tabular}

Local development plans: RYM (2008), RYM (2010), KKM (2010), KKM (2009), CMM (2009), CMM (2010)

not only from solid waste but also from transboundary air pollution from burning green waste in adjacent rural areas. Waste water is also a serious problem for this city particularly at the Mae$\mathrm{Ka}$ Canal, a major waterway in the city. Rush hour traffic congestion is a very serious problem in CMM. Thus, CMM works to solve these problems using various strategies. One can say that traffic especially rush hour is a serious problem for the three cities (CMM 2010). Both KKM and $\mathrm{CMM}$ have plans to enhance their mass transit systems to address traffic congestion. 
The Asian Institute of Technology and ADEME conducted a project called Bilan Carbone to help RYM and CMM to determine the amount of $\mathrm{CO}_{2}$ emitted by their activities and properties. Bilan Carbone is a software package developed by French Environment and Energy Management Agency (ADEME). Derived information was used to develop measures to reduce the amount of carbon dioxide $\left(\mathrm{CO}_{2}\right)$ released.

The $\mathrm{CO}_{2}$ emissions of three selected cities from two major sectors were examined. These sectors are waste management and electrical consumption. The data of other sectors such as transportation were not available. The amount of $\mathrm{CO}_{2}$ expressed in equivalent tons (eq.) was determined using Bilan Carbone software. Table 1 presents the $\mathrm{CO}_{2}$ eq. resulting from electrical consumption for each of the municipalities. CMM emitted the highest $\mathrm{CO}_{2}$ eq. This KKM and RYM followed in descending order. This is because CMM has the largest population so its electrical consumption was greatest. RYM is the smallest city among three selected cities in terms of population and area and therefore emitted fewer tons of $\mathrm{CO}_{2}$ eq. than the other two cities.

$\mathrm{CMM}$ also emitted the highest levels of $\mathrm{CO}_{2}$ eq. by waste sector followed by KKM and RYM in descending order. CMM is a center of business, tourism, and education in the Northern region. This causes generation of large amounts of waste and $\mathrm{CO}_{2}$ emissions. The demographic conditions of KKM in the Northeastern region are somewhat similar to CMM. Its $\mathrm{CO}_{2}$ eq. emissions were the second highest ( 84,315 t of $\mathrm{CO}_{2}$ eq.) of the three cities. $\mathrm{RYM}$ emitted the lowest emission in terms of tons of $\mathrm{CO}_{2}$ eq. emission from the waste sector and from electrical consumption.

The data of Table 1 and the environmental problems of three cities mentioned above suggest strategies and projects to solve pollution problems and conserve natural resources. Several things have already been done to promote climatic change mitigation. Major strategies and projects relevant with LCS activities are presented in the Table 2.

Only a few of the projects in Table 2 are city-wide initiatives. The rest were implemented in few communities, municipal schools, and selected sectors. The campaigns to promote $3 \mathrm{R}$ principles (Reduce-Reuse-Recycle), reducing energy consumption, and planting trees are the most common activities in the three cities to promote changes in people's behavior. There are no comprehensive projects implemented in any municipality to change people's lifestyles. This is a very challenging task for any municipality. All three municipalities actively engage in harnessing renewable energy and improving energy efficiency in municipal buildings and transportation. None of them have modern and clean public transport systems. City greening activities may not adequately contribute to (C) mitigation unless sizeable areas of land in the municipalities are converted to green spaces. RYM and CMM have already some LCS approaches into their respective urban development strategic plans. However, LCS approaches have not holistically formulated in any of the three cities. This is because there are existing limitations constraining local governments. These limitations are discussed below.

\section{Drivers influencing the adoption of LCS concepts}

The discussion above indicated that the selected municipalities have several initiatives which contribute to the achievement of LCS goals. It was necessary to determine factors influencing municipalities and stakeholders in implementing LCS programs. The researchers consulted key informants (i.e., individuals) representing the state and public service organizations in order to determine these factors. Their responses are summarized in Table 3. It was found that seven drivers were instrumental in influencing municipalities. However, none of them were strong drivers as indicated by WAI of 0.5341 to 0.5773 . This means that these factors have moderate influence on implementation of (C) emission reduction activities by municipalities. 
Table 3 Respondents' perception of drivers that contribute to carbon mitigation initiatives

\begin{tabular}{lllll}
\hline Drivers & \multicolumn{3}{l}{ Weighted average index (WAI) } & \\
\cline { 2 - 5 } & $\begin{array}{l}\text { RYM } \\
\left(n_{2}=36\right)\end{array}$ & $\begin{array}{l}\text { KKM } \\
\left(n_{2}=36\right)\end{array}$ & $\begin{array}{l}\text { CMM } \\
\left(n_{3}=38\right)\end{array}$ & $\begin{array}{l}\text { Total } \\
(N=110)\end{array}$ \\
\hline $\begin{array}{l}\text { 1. Technology transfer by a national/ } \\
\text { international development agency }\end{array}$ & $0.6387^{\mathrm{a}}$ & $0.6313^{\mathrm{a}}$ & $0.4706^{\mathrm{b}}$ & 0.5773 \\
$\begin{array}{l}\text { 2. Availability of financial incentives to invest } \\
\text { in cleaner technologies and infrastructure }\end{array}$ & $0.5944^{\mathrm{a}}$ & $0.5167^{\mathrm{b}}$ & $0.5895^{\mathrm{a}}$ & 0.5673 \\
$\begin{array}{l}\text { 3. Visionary political leadership to improve image } \\
\text { of the city at the local government level }\end{array}$ & $0.5935^{\mathrm{a}}$ & $0.5125^{\mathrm{b}}$ & $0.5765^{\mathrm{ab}}$ & 0.5608 \\
$\begin{array}{l}\text { 4. Dynamic leadership at the community } \\
\text { level and endogenous initiatives }\end{array}$ & $0.5935^{\mathrm{a}}$ & $0.5125^{\mathrm{b}}$ & $0.5529^{\mathrm{ab}}$ & 0.5526 \\
$\begin{array}{l}\text { 5. Knowledge and inspiration received from } \\
\text { workshops, site visits, role models, etc. }\end{array}$ & $0.5806^{\mathrm{a}}$ & $0.4937^{\mathrm{b}}$ & $0.5353^{\mathrm{ab}}$ & 0.5361 \\
$\begin{array}{l}\text { 6. Competitions launched by public/private agencies } \\
\text { to reward clean and green communities }\end{array}$ & $0.5613^{\mathrm{a}}$ & $0.5625^{\mathrm{a}}$ & $0.4824^{\mathrm{b}}$ & 0.5342 \\
$\begin{array}{l}\text { 7. Policy directives and guidelines issued } \\
\text { by government agencies }\end{array}$ & $0.5613^{\mathrm{a}}$ & $0.4938^{\mathrm{b}}$ & $0.5471^{\mathrm{ab}}$ & 0.5341 \\
\hline
\end{tabular}

Transfer of new technologies by national and international agencies is the highest ranked driver (0.5773) for implementing LCS initiatives. However, technology transfer did not influence the three municipalities to the same degree as indicated in Table 3. It was observed that RYM and KKM did receive technological support from the Energy Policy and Planning Office (EPPO) for implementing their alternative energy projects, i.e., conversion of plastic waste to synthetic oil. RYM and KKM received support from a private company in Europe through this program. However, CMM did not receive any such technological support. In addition, EPPO negotiated the price for acquiring the technology and subsidized a portion of the cost for RYM. KKM did not receive this subsidy. However, KKM plans a public-private partnership to acquire this technology. EPPO's strategy to provide technology at the local level produced positive results as indicated by significant statistical difference between those two municipalities. CMM did not experience such technology transfer.

These findings reveal that incentive policies motivated local politicians in RYM and KKM to enthusiastically collaborate with EPPO. Such projects help them to resolve municipal solid waste management problems thereby improving the environmental quality of their cities. Mitigation of (C) emissions is a co-benefit for them. This finding highlights that a co-benefit approach is an effective strategy for stimulating municipalities to conduct LCS projects as discussed by Laukkonen et al. (2009). The finding confirms that incentive policies are significant drivers because the first and second ranked drivers of monetary and non-monetary incentive policies.

Political leadership is a significant influencing factor for any local government. Table 2 indicates that visionary political leadership was the third most important influencing factor for implementing LCS activities in RYM and CMM. The mayor of RYM promoted environmental quality improvement strategies in the municipal area because of concern about transboundary pollution from Map Ta Put industrial estate, a well known source of environmental pollution in the country. In CMM, the mayor took a leading role in promoting environmental quality improvement strategies to make the city a more desirable tourist destination. Analysis of data suggests that the vision of the mayors of RYM and CMM was 
significantly different than for KKM. Dynamic leadership was the fourth most influential driver as shown in Table 3. It was found that 14 out of 27 communities in RYM have dynamic leadership that catalyzes community-based environmental improvement projects. However, the present research found that both political and community leadership are only moderately influential as indicated by WAI values of $0.41-0.60$. WAI values were 0.5608 and 0.5526 , respectively.

Although there were no significant differences among respective WAI values, knowledge and inspiration received through workshops, site visits and role models (0.5361) were slightly more influential than the policy directives issued by government agencies (0.5342), and the competitions organized by them to reward clean and green communities (0.5341). Among the three municipalities, RYM was the most driven by the policy directives and guidelines of government agencies. This is reflected in Table 2 by the greater number of strategies and (C) mitigation initiatives.

Overall, none of the seven drivers showed similar influence among all three municipalities. Pair-wise comparison of WAI values using the LSD test indicates similar influence of the respective drivers when comparing two municipalities but not in all three municipalities. The highest incidence of similarity is noted between RYM and CMM against five drivers. However, the inference of this finding is that no particular driver influences all local government bodies to implement $(\mathrm{C})$ emission reduction activities.

\section{Barriers affecting the adoption of LCS concept}

Although several (C) emission mitigation initiatives were launched, they were confined to communities and organizations as discussed above. The reasons are that these initiatives were not replicated throughout entire municipalities is unclear. In an attempt to clarify this issue, key informants' opinions regarding the barriers that affect adoption of LCS approaches are presented in this section. The summary results of data analysis are presented in Table 4. It shows that there are the four types of barriers. All types of barriers seem to be highly significant $(0.6100-0.8000)$, affecting the adoption of LCS approaches in the three municipalities. Among them, financial-economic barriers are the most significant, followed by institutional managerial barriers, social barriers, and technological barriers, in descending order of severity.

\subsection{Financial-economic barriers}

Among all the financial-economic barriers, inadequate municipal budget to acquire greener and cleaner technologies is the most highly influential $(0.8073)$. This was because the central government must supply $35 \%$ local governments' budget according to the Decentralization Act of 1999 . However, only $26.77 \%$ is now provided. Local governments have to rely heavily on revenue transferred to them by the central government. Local governments have the authority to collect taxes amounting to approximately $9 \%$ of their total revenue. The remainder is assigned by the central government in the form of grants in aid and revenue transfer (NMT 2012). Moreover, local governments spend an average of $43 \%$ of their budgets on administrative costs. The remainder is used for capital and special expenditures. Considering their functions (developing basic infrastructure, planning for investment and tourism, and conserving natural resources and environment) and there is always a revenue shortfall.

In the case of grants in aid, local politicians with good relationships with national politicians or strong national government lobbies can lead to receipt of larger portions of 
Table 4 Barriers affecting the adoption of LCS approaches in three selected Thai municipalities

Barriers

Weighted average index (WAI)

\begin{tabular}{llll}
\hline RYM & KKM & CMM & Total \\
$\left(n_{1}=36\right)$ & $\left(n_{2}=36\right)$ & $\left(n_{3}=38\right)$ & $(N=110)$
\end{tabular}

1. Financial-Economic Barriers (FEB)

- Inadequate municipal budget to acquire greener and cleaner

0.8073 technologies

- High cost to replace machinery, appliances and devices with more energy efficient ones

- Inadequate financial grants/subsidies to invest in green and clean infrastructure projects

- Overall Assessment of FEB

$\begin{array}{llll}0.6778 & 0.6833 & 0.6895 & 0.6836\end{array}$

. Institutional-Managerial Barriers (IMB)

- Insufficient direction and guidance by higher authorities to transform policies into local actions

- Absence of Policies \& Procedures to assign LCS activities to particular municipal divisions

- Lack of coordination among municipal office divisions of and the communities

- Absence of technically competent champions in the municipality to lead \& train other stakeholders

- Overall Assessment of IMB

$0.6333^{\mathrm{a}} \quad 0.6389^{\mathrm{a}} \quad 0.7105^{\mathrm{b}} \quad 0.6618$

$0.7000^{\mathrm{a}} \quad 0.7074^{\mathrm{ab}} \quad 0.7439^{\mathrm{b}} \quad 0.7176$

$\begin{array}{llll}0.6778 & 0.7222 & 0.6579 & 0.6855\end{array}$

$\begin{array}{llll}0.6667 & 0.7056 & 0.6737 & 0.6804\end{array}$

$0.6111^{\mathrm{a}} \quad 0.6833^{\mathrm{b}} \quad 0.6368^{\mathrm{ab}} \quad 0.6436$

$0.6056^{\mathrm{a}} \quad 0.6833^{\mathrm{b}} \quad 0.6105^{\mathrm{a}} \quad 0.6327$

$0.6602^{\mathrm{a}} \quad 0.7042^{\mathrm{b}} \quad 0.6569^{\mathrm{a}} \quad 0.6735$

3. Social Barriers (SOB)

- Carbon emission reduction was not an issue commonly understood by ordinary people

- Insufficient priority placed by community leaders on activities related to LCS activities

- Insufficient participation by people and other stakeholders in city-wide activities

- Local politicians pay more attention to their districts and less on city-wide activities

- People did not want to sacrifice their personal comfort and convenience for energy saving

- Overall Assessment of SOB

$\begin{array}{cccc}0.7000 & 0.7389 & 0.7263 & 0.7218 \\ 0.6167^{\mathrm{a}} & 0.6889^{\mathrm{b}} & 0.6526^{\mathrm{ab}} & 0.6527\end{array}$

$0.6000^{\mathrm{a}} \quad 0.6778^{\mathrm{b}} \quad 0.6579^{\mathrm{ab}} \quad 0.6455$

$0.6000^{\mathrm{a}} \quad 0.6944^{\mathrm{b}} \quad 0.6368^{\mathrm{a}} \quad 0.6436$

$\begin{array}{llll}0.6222 & 0.6444 & 0.6474 & 0.6382\end{array}$

$0.6278^{\mathrm{a}} \quad 0.6889^{\mathrm{b}} \quad 0.6642^{\mathrm{b}} \quad 0.6604$

4. Technological Barriers (TEB)

- Insufficient capacity to operate and maintain advanced technologies

- Lack of access to energy efficient appliances and greener technologies

- Doubts on the appropriateness and efficiency of greener technologies to solve local environmental problems

- Overall Assessment of TEB

$\begin{array}{llll}0.6278 & 0.6444 & 0.6579 & 0.6436\end{array}$

$0.5556^{\mathrm{a}} \quad 0.5778^{\mathrm{a}} \quad 0.7263^{\mathrm{b}} \quad 0.6218$

$\begin{array}{llll}0.5833 & 0.6167 & 0.6263 & 0.6091\end{array}$

$0.5889^{\mathrm{a}} \quad 0.6130^{\mathrm{a}} \quad 0.6702^{\mathrm{b}} \quad 0.6248$

their budgets from the central government. Local government enjoying no such relationships cannot access funds, even if they have good projects to implement. Due to non-transparent purchasing processes, some local governments and private companies may misappropriate funds when tendering project bids. This is a fundamental problem at local levels (Wongpreedee 2012). As such, the central government must manage projects with high 
investment costs to prevent corruption at local levels. Moreover, municipalities must obtain approvals for their expenditure plans by at the provincial level by their governor. So municipalities do not have the independence to invest in high cost projects. This represents a significant financial. For this reason, investment in low (C) technology special projects is beyond the financial capacity of most local government bodies in Thailand.

Table 3 shows that technology and financial incentives were the most influential drivers to implement LCS activities in RYM and KKM. Table 4 reveals that financial-economic barriers are the most significant in influencing acquisition of low $(C)$ technologies for these municipalities. In the case of CMM, which has not received any financial incentives, financial barriers are the most serious as indicated by its WAI score (0.8316). The multiple comparison of WAI indicates that CMM's experience was significantly more severe than for RYM and KKM. Table 3 also reveals that the cost to replace existing machinery, appliances with more energy efficient ones is not feasible for the municipalities of the current study (0.6836). If financial barriers are so severe for these municipalities, other municipalities not having such favorable conditions face barriers face even greater obstacles.

\subsection{Institutional-managerial barriers}

The second most serious barrier is institutional and managerial constraints. Insufficient direction and guidance by national authorities to transform policies to local actions was attributed as an external barrier by the respondents. A WAI value of 0.6855 indicated it was a highly influential barrier to implementing LCS activities in the municipalities. Simply stated, the survey respondents representing governmental agencies did not have requirements to implement national climatic change mitigation policies in their jurisdiction. Lack of strong direction from national authorities reflects the absence of enabling policies and procedures within these municipalities. This factor was found to be highly influential (0.6804). It suggests there are both local external and internal institutional barriers that affect the implementation of LCS. Lacking LCS policies by local authorities, responsibility for implementation of LCS activities will not be accepted by any particular division. For example, KKM was a partner of the Khon Kaen Declaration on Low Carbon Cities (LCC) since 2009. However, KKM has not yet adopted any explicit strategies to become a LCC. Politicians in KKM are more interested pursuing the goal of being economic hub of the Northeastern region. In the RYM where several (C) mitigation projects have been implemented, there was no internal policy consistent with LCS goals to direct its officials. As revealed in interviews with key informants, overall improvement of environmental quality of RYM is its priority but not specifically through (C) mitigation. This is true of CMM as well. This means RYM and CMM just implement the projects to address natural and environmental conditions with the functions transferred to them from the central government. In this case, the major objective of such projects is not for climate change mitigation and there is no policy framework explicitly formulated for these two cities to engage in LCS projects. However, RYM and CMM have formulated a greater number of strategies and projects related to LCS than KKM. In all municipalities, urban environmental quality management is a routine task distributed among the divisions.

As Wiruchnipawan (2003) discussed, municipal officers generally will not accept new responsibilities in addition to their routine tasks. Poor coordination between municipal divisions is a strong internal barrier to implementing collaborative LCS activities. This extends to a state of poor coordination between municipalities, communities, and other stakeholders. It is the collective perception of the respondents that lack of coordination within their municipality and between their municipality and the stakeholders severely inhibits adoption of LCS approaches. This perception is reflected by a WAI of 0.6436 and 
in pair-wise comparisons. The relations between RYM and CMM as well as between KKM and $\mathrm{CMM}$ are statistically similar.

Moreover, the lack ability to lead other stakeholders in municipalities is a barrier in RYM and CMM as well. These two municipalities are well regarded within the country for their environmental stewardship. The above finding implies that both political and technical leadership are critical for successful transformation into LCS.

\subsection{Social barriers}

Findings reveal that climatic change mitigation is not an issue that is well understood by ordinary people. This leads to their collective inaction. This is the most influential social barrier affecting the adoption of LCS activities by local authorities as indicated by WAI (0.7218). Community leaders place less priority on LCS activities when community members are not enthusiastic about participating in (C) mitigation. Attitudes about climatic change influence peoples' actions on adopting or rejecting mitigation activities (Winkler et al. 2007). Research findings confirm this assertion. Moreover, they reveal that public service organizations and their political leaders pay less attention to implementation city-wide activities. Such attitudes are a significant barrier (0.6400) to $\mathrm{CO}_{2}$ reduction activities. This finding also explains the stumbling block for scaling up successful community-based environmental management activities to city-wide activities. For example, only 15 out of 90 communities in KKM actively collaborate in the municipality's recycling project promoting separation of solid-waste at its source. Lack of participation by major communities has become a barrier at the very first step of the process. Participants revealed that community members do not actively participate due to a variety of reasons. These included insufficient personal/financial benefits from waste separation at source, lack of spare time for community activities, attitudes of "why we should do the waste handlers' work" among the entire population, and an "it is none of our affair" attitude of unregistered people who account for $30-40 \%$ of the total population in each municipality. These were the most common reasons for non-participation by the community members.

Findings also reveal that peoples' reluctance to sacrifice their personal comfort is a significant barrier $(0.6382)$ to promoting activities for energy saving. No dissimilarity was observed among the three municipalities regarding this issue. Pair-wise comparison of WAI values indicated that social barriers faced by RYM are significantly less that when compared to KKM and CMM. This situation can be attributed to the relatively small size of RYM. In contrast, KKM and CMM do not show significant differences in social barriers. Overall assessment of WAI (0.6604) indicates that social barriers significantly influence the adoption of LCS approach in all three municipalities. The inference of this finding is that community based or stakeholder focused activities for (C) emission reduction need to be augmented by more effective persuasive strategies and tangible incentives.

\subsection{Technological barriers}

Utilizing low (C) technologies is one of the major strategies for LCS approaches. Financial barriers for acquiring necessary equipment and technologies are discussed above in Section 6.1. This section discusses the technological barriers related to their operation and maintenance. The respondents revealed that insufficient ability to operate and maintain low (C) technological devices was a significant barrier (0.6436). For example, gasification technology (turning bio-degradable waste to energy) installed in RYM was not operating during the field survey for several reasons. Although, its operation is not complicated but 
technical staff were not capable of making repairs when breakdowns occurred. Secondly, they have to rely on the private companies that possess patents/franchises for those technologies for any major maintenance or repair task. Thirdly, repairs and maintenance of patented machinery cannot be made by their staff. RYM installed technology to demonstrate its environmental responsibility without the goal of financial gain. Still maintenance and repair accosts were their greatest burden. For similar reasons, Phitsanuloke municipality in central Thailand abandoned their mechanical-biological waste treatment system which was based on a patented technology transferred Europe. This discouraged other municipalities from venturing into acquisition of advanced and cleaner technologies. Survey result show that doubts about the appropriateness and efficiency of greener technologies to solve local environmental problems was a moderately influencing technological barrier (0.6091).

Lack of access to energy efficient appliances and cleaner technologies was a significant barrier, especially for CMM (0.7263). Unlike RYM and KKM which benefitted from technology transfer facilitated by EPPO, CMM has not had access to any local or international source of low (C) technologies. This situation is evidenced by the soft kind of interventions implemented by CMM, as seen in Table 2. According to the pair-wise comparison, RYM and KKM are only moderately affected by the lack of access to energy efficient appliances and cleaner technologies. The overall assessment confirms that CMM is more affected by technological barriers than either RYM or KKM. The findings suggest that any technology transfer should address four aspects of technology: 1) Technoware (object embodied technology), 2) Humanware (person embodied technology), 3) Infoware (document embodied technology) and 4) Orgaware (institution embodied technology) (Sharif 1987). This should be done so that municipalities have competencies to handle technology-driven strategies for LCS projects.

According to the overall WAI assessment for each municipality, CMM benefitted least from external development partners and seem to experience more financial-economic and technological barriers than did RYM and CMM. In contrast KKM, which did not demonstrate strong state-society relationships, seemed to experience more institutional-managerial and social barriers than the other two municipalities. RYM, a small municipality with a visionary political leadership and strong relationship between communities, stakeholders and public service organizations, seem to be least affected by the four types of barriers. This condition was evident from the lower and significantly different values for WAI assessment for the four types of barriers. It can be concluded that none of the four types of barriers affected the three municipalities in the same way.

\section{Lessons learned}

This article presents the drivers and barriers influencing integration of LCS activities with strategies of three selected second-tier urban municipalities in Thailand. It also presents the current conditions relevant to the capabilities of local government in a developing country attempting to assume responsibility for (C) mitigation by applying LCS principles. Under the influence of drivers and limitations, there are some points of view that are useful in local contexts for the other developing countries.

First, governmental policy directives and guidelines on LCS activities are the least influential while financial subsidies and transfer of technologies are the most influential drivers. These findings imply that governmental policy directives should be coupled with technology transfer and financial incentives in order to improve the effectiveness of implementing national climatic change policies at local levels. Without such incentives, 
the authorities and stakeholders of the local government bodies are unlikely to engage in self-driven and community-based environmental quality improvement initiatives with the goal of developing an integrated set of actions to achieve a LCS.

Regarding financial incentives and technology transfer, low (C) technological machinery is expensive and difficult to maintain. Subsidies are a suitable method to stimulate local governments and stakeholders to pursue such technological solutions. However, it is essential to consider the existing capabilities of local governmental agencies. Not every local government receiving assistance can succeed in use of low (C) technological machinery. As observed in RYM, there are several problems regarding management of these types of projects. In RYM, malfunctioning machinery could not be repaired. This was due to a lack of technical knowledge and documentation. One can conclude that this was not a worthy investment because such modern machinery could not be utilized. Public private partnerships (PPP) or outsourcing is another suitable method to help local government to handle projects like these. It was proposed in an earlier study (IGES 2011) that PPP could positively affect management of decarbonization projects. For example, CMM contracted with a private company to eliminate solid waste within its municipality. The same company also operates and maintains gasification machinery relieving CMM of potential operational risks.

Market mechanisms are another tool to help support PPP techniques. This technique can be used stimulate interest of private companies to participate in municipal projects. In Thailand, TGO promoted a (C) credit market to inspire organizations to engage in mitigation activities. This seems to be an important method by which the central government can use as a market mechanism. Benefits for such private companies are necessary as discussed in earlier work (Hall and Wreford 2012). However, the attitude of private sector toward the government agencies can be different by countries or regions. This is depend on how supportive the local law and regulations would encourage the cooperation between both parties. Also, the operational nature of public sector is basically procedure-oriented, instead of goal oriented of private sector. This is because the governmental operational procedures must be strictly abided by the laws and regulations. Otherwise, the lawsuit or disciplinary actions are subjected to be administered which could result in severe damage in term of both financial and non-financial aspects.

Local governments in the same region could work together in special districts. This could produce large scale benefits for many municipalities. Low (C) machinery such as gasification and polymer technology needs sufficient raw materials to operate efficiently. Special districts can efficiently accumulate enough raw materials for operation of such machinery (King Prajadhipok's Institute 2007; Senate Local Government Committee 2010). However, the operational culture of each individual municipality must be highly in consideration. This would affect the success of the collaboration among municipalities since the difference in the individual municipal capability would affect the performance of entire municipal collaboration which will eventually affect the quality of citizen service delivery.

The research findings also reveal that other technology-related barriers exist such as lack of technically competent staff (i.e., humanware), insufficient access to patented technological information (i.e., infoware) and, weaknesses in the organization structure of the municipalities (i.e., orgaware). These highly influenced the adoption of LCS agendas in the three municipalities of the current study. To overcome these problems, stakeholders need to assist local government agencies to undertake LCS activities. Hillmer-Pegrama et al. (2012) suggested that universities have their own knowledge of (C) mitigation that can useful to local government agencies. Moreover, academic institutions have capabilities to link funds from international organizations to budgets at local levels. For example, the Asian Institute of Technology in conjunction with ADEME initiated the Bilan Carbone project with RYM 
and CMM. These institutes contributed a portion of money and knowledge for RYM and CMM to conduct this project. The Bilan Carbone project helped two municipalities to determine the amount and the major sectors of GHG emission by their activities. Then, the cities found suitable ways to reduce GHG emissions. However, local government efforts are needed to encourage their officials to work with external agencies. Rewards and incentives have been used in the past to encourage local officials to work towards these goals (Kwon and Jang 2011). This can positively affect the situation to attract the assistance of other the stakeholders.

The research confirms that not only technically competent staff but also visionary and supportive community leadership are critical for successful LCS transformation of societies. Political determination is a strong variable influencing the adoption of climatic policies (HillmerPegrama et al. 2012; Winkler et al. 2007). However, not every local politician is interested to climate change issues and political will is low mostly in many developing countries (Dhakal 2010). It is also difficult to compel political leaders to accept LCS initiatives because there is no directive requiring them to do so and there are other public services that they consider important than climate change issues (Dulal and Akbar 2013). In reality most local government agencies are poorly managed, have weak organizational structure and lack financing.

Our study found that local governments that face serious environmental problems such as air pollution and solid waste are more likely to engage with climatic change mitigation activities than those not faced with such problems. Thus, local leaders are somewhat familiar with and interested in the issue of climatic change mitigation. They are likely to formulate specific strategies and implement activities consistent with (C) mitigation. Streimikiene et al. (2012) suggested that to develop climatic change policies, the first step should be to assess local themes and relate them to climatic change. Solutions to both can be promoted simultaneously. In this way, interest in climatic change issues among local leaders can be motivated.

Lastly, promoting the principle of multiple benefits of climate change mitigation in developing countries is another advantage at local level. Kousky and Schneider (2003) asserted that local governments are primarily driven by the potential for realized or perceived co-benefits, such as cost savings, rather than by state pressure. Such approaches can reduce GHG emissions and give benefits to people, especially the vulnerable groups in society (Laukkonen et al. 2009). However, creating local government policies that derive co-benefits for (C) mitigation and sustainable development is not easy. University assistance is not enough to help municipalities in this regard. The current study suggests promoting participation of community and public service organizations is necessary in municipal planning to formulate this kind of policy. The current study and that of Kaewhanam (2012) found that KKM has one of the highest rates of stakeholder involvement in municipal planning processes. Stakeholders realize satisfaction in their participation. Hardoy and Lankao (2011) suggested that stakeholders can share experiences that contribute to (C) mitigation policies. However, Thailand is democratic. The citizen participation is highly encouraged in all level of governance. For example, the public hearing regarding the government mega projects which will significantly impact citizen. Hence, the degree of citizen participation could be different by countries, depending on the political culture, social contexts, and citizen's literacy rate.

\section{Conclusions}

Local government units works closely with their constituents. In doing so, they can respond to local and global needs. Climatic change mitigation is one of the latest responsibilities of 
local governments in developing countries. However, most local governments give much more attention issues of their local economy and basic infrastructure than to climatic change mitigation. Simultaneously, they are confronted by limitations that affect their abilities to integrate LCS approaches with their strategies.

There are four major conclusions resulting from the current study. Firstly, the major barriers can be classified into four groups. These are financial, technological, social, and managerial barriers. Secondly, the most serious group of barriers is financial barriers. Managerial, social, and technological barriers are respectively of descending severity. Thirdly, there is a group of drivers promoting implementation of LCS approaches by local governments. The drivers are incentive policy (finance and technology transfer), political willingness, support of community leadership, and policy directives. Lastly, the most important driver is incentive policy from the central government (finance and technology transfer). This is because central governments can apply these kinds of measures as tools to encourage local governments to participate in LCS activities. This is particularly useful for projects requiring high levels of investment.

This study suggests that PPP or outsourcing techniques can help alleviate the financial and technological limitations of local government for high investment projects. The role of public service organizations and communities in policy decision making processes reinforces the ability of local governments to formulate LCS strategies in accordance with local and global needs. The authors recommend that focusing on local themes relevant to (C) mitigation and promotion of climatic change mitigation policies that have co-benefits can be effective instruments to inspire local planners to integrate LCS measures with municipal strategies. The authors believe that the details presented here will be useful to those interested in reducing $\mathrm{CO}_{2}$ emissions and modifying to (C) mitigation strategies at city level. Moreover, the local contexts of each individual city must be highly in consideration.

Open Access This article is distributed under the terms of the Creative Commons Attribution License which permits any use, distribution, and reproduction in any medium, provided the original author(s) and the source are credited.

\section{References}

APEC (Asia-Pacific Economic Cooperation) (2010) The 2050 scenario: low carbon high quality lifestyle for the ASIA-PACIFIC. APEC center for technology foresight, Bangkok

Bader N, Bleischwitz R (2009). Study report: comparative analysis of local GHG inventory tools. http:// www.institut.veolia.org/ive/ressources/documents/2/491,Final-report-Comparative-Analysis-of.pdf (Accessed 3.8.10)

Becken S (2005) Harmonizing climate change adaptation and mitigation: the case of tourist resorts in Fiji. Glob Environ Chang 15(4):381-393

Betsill MM (2001) Mitigating climate change in US Cities: opportunities and obstacles. Local Environment 6 (4):393-406

Burch S (2010) Transforming barriers into enables of action on climate change: insights from three municipal case studies in British Columbia, Canada. Glob Environ Chang 20:287-297

Byrne J, Hughesa K, Rickersona W, Kurdgelashvili L (2007) American policy conflict in the greenhouse: divergent trends in federal, regional, state, and local green energy and climate change policy. Energy Policy 35:4555-4573

CMM (Chiang Mai Municipality) (2009) Three years development plan of Chiang Mai Municipality. Chiang Mai Municipality, Chiang Mai

CMM (Chiang Mai Municipality) (2010) Chiang Mai municipality annual report. Chiang Mai Municipality, Chiang Mai

Dhakal S (2010) GHG emissions from urbanization and opportunities for urban carbon mitigation. Curr Opin Environ Sustain 2:277-283 
Dulal HB, Akbar S (2013) Greenhouse gas emission reduction options for cities: finding the "Coincidence of Agendas" between local priorities and climate change mitigation objectives. Habitat Int 38:100-105

Fleming PD, Webber PH (2004) Local and regional greenhouse gas management. Energy Policy 32:761-771

Garbuzova M, Madlener R (2012) Towards an efficient and low carbon economy post-2012: opportunities and barriers for foreign companies in the Russian energy market. Mitig Adapt Strat Glob Chang 17:387-413

Grimmond CSB, Rothb M, Okec TR, Aud YC, Beste M, Bettse R, Carmichaelf G, Cleughg H, Dabberdth W, Emmanuelj R, Freitasj E, Fortuniakk K, Hannal S, Kleinm P, Kalksteinn LS, Liuo CH, Nicksonp A, Pearlmutterq D, Sailorr D, Voogts J (2010) Climate and more sustainable cities: climate information for improved planning and management of cities (producers/capabilities perspective). Procedia Environ Sci 1:247-274

Hall C, Wreford A (2012) Adaptation to climate change: the attitudes of stakeholders in the livestock industry. Mitig Adapt Strat Glob Chang 17:207-222

Hardoy J, Lankao PR (2011) Latin American cities and climate change: challenges and options to mitigation and adaptation responses. Curr Opin Environ Sustain 3:158-163

Hillmer-Pegrama KC, Howe PD, Greenberg H, Yarnal B (2012) A geographic approach to facilitating local climate governance: from emissions inventories to mitigation planning. Appl Geogr 34:76-85

IGES (2011) Synthesis report of transition towards low carbon societies in Thailand and Asia-dialogue between policy-makers and researchers and cross-sectoral approach, Institute for Global Environmental Strategies (IGES), Japan

IGES (Institute for Global Environmental Strategies) (2008) The climate regime beyond 2012; Reconciling Asian Priorities and Global Interests. Japan, pp 89

IPCC (Intergovernmental Panel on Climate Change) (2007) Climate Change 2007: mitigation of Climate Change. Contribution of Working Group III to the Fourth Assessment Report of the Intergovernmental Panel on Climate Change. Cambridge University Press, Cambridge

Jaber JO (2002) Greenhouse gas emissions and barriers to implementation in the Jodanian energy sector. Energy Policy 30:385-395

Kaewhanam K (2012) Participation in municipality development planning: the comparison of Khon Kaen Municipality and Kalasin Municipality. Thai J Public Adm 10:39-66

Kheshgi H, Coninck H, Kessels J (2012) Carbon dioxide capture and storage: seven years after the IPCC special report. Mitig Adapt Strat Glob Chang 17:563-567

King Prajadhipok's Institute (2007) cooperation among local government: form and possibility. King Prajadhipok's Institute, Bangkok

KKM (Khon Kaen Municipality) (2009) The strategic plan of Khon Kaen Municipality (2012-2014). Khon Kaen Municipality, Khon Kaen

KKM (Khon Kaen Municipality) (2010) Three years development plan of Khon Kaen Municipality (20112013). Khon Kaen Municipality, Khon Kaen

Koh SL, Lim YS, Morris S (2011) Potential of advanced coal and gas combustion technologies in GHG emission reduction in developing countries from technical. Environ Econ Perspect Procedia 12:878-885

Kousky C, Schneider SH (2003) Global climate policy: will cities lead the way? Clim Pol 3:359-372

Kwon M, Jang HS (2011) Motivations behind using performance measurement: citywide vs. selective users. Local Government Studies 37:601-620

Larsen K, Gunnarsson-Ostling U (2009) Climate change scenarios and citizen-participation: Mitigation and adaptation perspectives in constructing sustainable futures. Habitat Int 33:260-266

Laukkonen J, Blanco PK, Lenhart J, Keiner M, Cavric B, Kinuthia-Njenga C (2009) Combining climate change adaptation and mitigation measures at the local level. Habitat Int 33:287-292

Liu J, Deng X (2011) Impacts and mitigation of climate change on Chinese cities. Curr Opin Environ Sustain 3:188-192

Lorenzoni I, Nicholson-Coleb S, Whitmarsh L (2007) Barriers perceived to engaging with climate change among the UK public and their policy implications. Glob Environ Chang 17:445-459

Lybbert TJ, Sumner DA (2012) Agricultural technologies for climate change in developing countries: policy options for innovation and technology diffusion. Food Policy 37:114-123

MOEJ (Ministry of the Environment) (2007) Building a low carbon society-2007. Ministry of the Environment, Japan

NESDB (National Economic and Social Development Board) (2009) Clean technology fund investment plan for Thailand. http://www.nesdb.go.th/Portals/0/home/interest/09/Final_Draft_CTF_InvestmentPlan Oct09.pdf. Accessed 25 November 2011

NESDB (National Economic and Social Development Board) (2010) The study in case of non-registered population of Rayong province. NESDB, Bangkok

NMT (The National Municipal League of Thailand) (2008) The manual of climate change mitigation for local authorities in Thailand. The National Municipal League of Thailand, Bangkok 
NMT (The National Municipal League of Thailand) (2012) The comparison of budget allocation for local government of the year 2007-2012. www.nmt.or.th/DocLib14/2555/chart\%20distribution\%2049-55.pdf Accessed 15 March 2013

Oberheitmann A (2012) $\mathrm{CO}_{2}$-emission reduction in China's residential building sector and contribution to the national climate change mitigation targets in 2020. Mitig Adapt Strat Glob Chang 17:769-791

Oliveira JAP (2009) The implementation of climate change related policies at the sub-national level: an analysis of three countries. Habitat Int 33:253-259

ONEP (Office of Natural Resources and Environmental Policy and planning) (2009) National Master Plan on Climate Change 2010-2019. Office of Natural Resources and Environmental. Policy and planning, Bangkok

Orlansky D (2000) Decentralization politics and policies. In: Nagel SS (ed) Critical issues in Cross-national public administration: privatization, democratization, decentralization. Greenwood Publishing, USA

Paung-ngum K (2005) Thai local administration. Vinyuchon, Bangkok

Roy M (2009) Planning for sustainable urbanization in fast growing cities: mitigation and adaptation issues addressed in Dhaka, Bangladesh. Habitat Int 33:276-286

Rübbelke DTG (2011) International support of climate change policies in developing countries: Strategic, moral and fairness aspects. Ecol Econ 70:1470-1480

RYM (Rayong Municipality) (2008) Five years strategic plan of Rayong Municipality (2009-2013). Rayong Municipality, Rayong

RYM (Rayong Municipality) (2010) Three year development plan of Rayong Municipality (2011-2013). Rayong Municipality, Rayong

Senate Local Government Committee (2010) What's so special about special districts? Senate Local Government Committee http://www.inyocounty.us/Recorder/.../Whats_So_Special.pdf. Accessed 25 March 2013

Sharif MN (1987) Components of technology for resources transformation. Technol Forecast Soc Chang 32:19-35

Skea J, Nishioka S (2008) Policies and practices for a low-carbon society. http://www.fao.org/fileadmin/user upload/rome2007/docs/Policies\%20and\%20practices\%20for\%20a\%201ow-carbon\%20society.pdf. Accessed 25 June 2010

Smith DM (2006) Just one planet: poverty. Justice and climate change, Ashford

Stephens JC, Wilson EJ, Peterson TR (2008) Socio-Political Evaluation of Energy Deployment (SPEED): an integrated research framework analyzing energy technology deployment. Technol Forecast Soc Chang 75:1224-1246

Streimikiene D, Entis TB, Iukaitien IK (2012) Promoting interactions between local climate change mitigation, sustainable energy development, and rural development policies in Lithuania. Energy Policy 50:699-710

TAT (Tourism Authority of Thailand) (2010) Tourism Investment: Geo-informatic system. Accessed 26 January 2013

TGO (Thailand Greenhouse Gas Management Organization) (2007) The history of Thailand Greenhouse Gas Management Organization. http://www.tgo.or.th/index.php?option=com_content\&view=category\&id= 29\&Itemid=28. Accessed 26 November 2011

Tompkins EL, Adger WN (2005) Defining response capacity to enhance climate change policy. Environ Sci Policy 8:562-571

TRF (Thailand Research Fund) (2010) Challenge-policy recommendation and the negotiation of the World Climate Change. Thailand. http://measwatch.org/book/7. Accessed 12 June 2012

Vadas TM, Fahey TJ, Sherman RE, Demers JD, Grossman JM, Maul JE, Melvin AM, O’Neill B, Raciti SM, Rochon ET, Sugar DJ, Tonitto C, Turner CB, Walsh MJ, Xue K (2007) Approaches for analyzing local carbon mitigation strategies: Tompkins Country, New York, USA. Int J Greenhouse Gas Control 1(3):360-373

Vijayavenkataraman S, Iniyanb S, Goicc R (2011) A review of climate change, mitigation and adaptation. Renew Sust Energ Rev 16:878-897

Wang C, Cai W, Lu X, Chen J (2007) $\mathrm{CO}_{2}$ mitigation scenarios in China's road transport sector. Energy Conserv Manag 48:2110-2118

Winkler H, Baumert K, Blanchard O, Burch S, Robinson J (2007) What factors influence mitigative capacity? Energy Policy 35:692-703

Wiruchnipawan W (2003) Municipality administration and management under the political reform era. Forepace Publishing House, Bangkok

Wongpreedee A (2012) Local fiscal problems in Thailand: the perceptions of municipal mayors. J Public Priv Manag 19:1-27

Yuan H, Zhoua P, Zhoua D (2010) What is low-carbon development? A conceptual analysis. Energy Procedia 5:1706-1712

Zhang Z, Maruyama A (2001) Towards a private-public synergy in financing climate change mitigation projects. Energy Policy 29:1363-1378 